\title{
The Trans-Pacific Partnership Agreement: challenges for Australian health and medicine policies
}

\author{
Thomas A Faunce and Ruth Townsend
}

T he Trans-Pacific Partnership Agreement (TPPA) is a free trade agreement (FTA) relic from the era of financial markets deregulation, initiated by the United States Trade Representative (USTR) just before the global financial crisis. ${ }^{1}$ Despite most developed economies now embracing re-regulation, four formal rounds of TPPA negotiations took place in 2010 (Melbourne - March, San Francisco - June, Peru — August and Brunei - October). These involved over 200 officials from Australia, the US, New Zealand, Chile, Singapore, Brunei, Peru, Vietnam and Malaysia discussing three major issues (as notified to the public in characteristically terse and opaque terminology) with public health and medicines policy implications for Australia:

- ensuring regulatory coherence and transparency;

- benefiting multinationals and small-medium enterprises (SMEs); and

- improving multilateral "investor-state dispute settlement". 2

In this article, we seek to elucidate the likely content and impact of these issues, chiefly by examining influential US industry submissions to the USTR on the TPPA.

\section{Ensuring regulatory coherence and transparency}

The TPPA is a multilateral FTA. Similar multilateral FTAs influencing Australian domestic public health and medicines policies include the World Trade Organization (WTO) Agreement on Trade-Related Aspects of Intellectual Property Rights (TRIPS) (which required, for instance, increased pharmaceutical patent terms under threat of trade sanctions) and the General Agreement on Trade in Services (which allowed signatories to facilitate foreign corporate ownership of, for example, hospital or dental services). ${ }^{3}$ More recently, bilateral US FTAs such as the Australia-US Free Trade Agreement (AUSFTA) have included additional provisions (known as "TRIPS-Plus" [or "Doha-Minus"]) influencing health and medicines policy (Box 1). ${ }^{4}$

The US agenda in TPPA negotiations will be greatly influenced by submissions made to the USTR by Pharmaceutical Research and Manufacturers of America (PhRMA), the US patented pharmaceutical lobby. ${ }^{5}$ PhRMA requested that the TPPA negotiations

address ... market access barriers, remedy inadequate consultative mechanisms and transparency concerns in countries, like New Zealand, for which no US FTA currently exists ... [in doing so this would] ensure that patients throughout the TPP region receive safe, effective and innovative [emphasis added] medicines. ${ }^{6}$

The above language (particularly the replacement of "costeffective" with "effective and innovative") suggests that one aspect of TPPA "regulatory coherence and transparency" negotiations (at least from the US perspective) may involve incorporating into the TPPA so-called TRIPS-Plus provisions (Box 1) from earlier bilateral US FTAs. The contradictory relationship of such provisions with the Doha Declaration on TRIPS and Public Health ${ }^{7}$ and their potentially deleterious impacts on public health, have been documented by a World Health Organization commission. ${ }^{8}$ Australia has already been exposed to these through the combined operation
ABSTRACT

- Four formal rounds of Trans-Pacific Partnership Agreement (TPPA) negotiations took place in 2010. They involved over 200 officials from Australia, the United States, New Zealand, Chile, Singapore, Brunei, Peru, Vietnam and Malaysia.

- Future negotiations officially are set to include three issues with public health and medicines policy implications for Australia and our region:

$>$ ways to approach regulatory coherence and transparency; $>$ how to benefit multinational and small-medium enterprises; and

$>$ multilateral investor-state dispute settlement.

- US-based multinational pharmaceutical companies are lobbying for TPPA provisions like those in the Australia-US Free Trade Agreement, which reduce government costeffectiveness regulatory control of pharmaceuticals, threatening equitable access to medicines.

- They also advocate increased TPPA intellectual monopoly privilege protection, which will further limit the development of Australian generic medicine enterprises and restrict patient access to cheap, bioequivalent prescription drugs.

- Of particular concern is that proposed TPPA multilateral investor-state dispute settlement procedures would allow US corporations (as well as those of other TPPA nations) to obtain damages against Australian governments through international arbitral proceedings if their investments are impeded by Australian public health and environment protection legislation.

MJA 2011; 194: 83-86

of AUSFTA Chapter 17 (on intellectual monopoly privileges) and Annex 2C (on changes to the Australian Pharmaceutical Benefits Scheme [PBS]). ${ }^{9}$ The PhRMA TPPA submission also seeks provisions ensuring its members' intellectual monopoly privileges are not "undermined by other government pricing and regulatory mechanisms" (such as cost-effectiveness research [CER] and reference pricing systems) which it contentiously refers to as "nontariff" barriers to "innovative medicines". 6

The TPPA submission by the US patented pharmaceutical company Novartis requests "enhanced cooperation among the TPP participants' respective drug authorities", prevention of market entry by substandard medicines, as well as a Medical Devices and Pharmaceuticals Working Group to facilitate ongoing private sector lobbying. ${ }^{10}$ This raises concern, as the AUSFTA similarly created a Medicines Working Group that arguably promoted changes to the reference-pricing system of Australia's PBS. ${ }^{4}$

\section{Benefiting multinationals and small-medium enterprises}

In its efforts to promote the interests of US multinationals and SMEs, PhRMA continues to recommend that the governments of 
1 "TRIPS-Plus" ("Doha-Minus") provisions from United States bilateral free trade agreements

- Linkage evergreening: drug safety regulators notify patent holder of impending generic entrant to the market - facilitates promonopolistic and anti-competitive strategies against generic medicines.

- Data exclusivity: may inhibit generic companies from using data on patented medicines submitted to safety regulators even to prepare for rapid launch upon patent expiry ("springboarding") or satisfy compulsory licensing.

- Anti-parallel importation: prohibits re-importation of medicines made cheaper by the drug regulatory system of another nation.

- Compulsory licensing restrictions: limit the situations under which, in public health emergencies, governments can grant licences to generic companies to rapidly produce necessary medicines with minimal compensation to the patent holder.

- Anti-reference pricing provisions: in the guise of promoting the "competitive markets" rather than alternate "objectively demonstrated therapeutic significance" approach to assessing pharmaceutical "innovation" (both specified in Annex 2C.1 of the AUSFTA) - limit the capacity of governments to establish Pharmaceutical Benefits Scheme-type cost-effectiveness assessment and central government price negotiation systems for new health technologies.

- Patent extension for delayed marketing approval — even when delay due to inadequate information presented to safety regulators.

TRIPS = Trade-Related Aspects of Intellectual Property Rights. AUSFTA = Australia-US Free Trade Agreement.

Australia, Chile, NZ, Peru, Vietnam and Malaysia be placed on the USTR's Special 301 Watch List because their domestic legislation allegedly inadequately protects US pharmaceutical patents and interests. ${ }^{11}$ A recent PhRMA submission to the USTR on this Watch List seeks to have Australia placed on it due a variety of matters including Australia's failure to regularly convene the AUSFTA medicines policy lobby group. ${ }^{12}$

PhRMA also protested about the impact on its corporate members of Australia's "anti-evergreening" amendments to the Therapeutic Goods Act 1989 (Cwlth) that were passed as a condition of AUSFTA coming into force, as well as against the possibility that the Australian Patents Act 1990 (Cwlth) might be amended to allow the manufacture of generic medicines for export to international markets where relevant patents have expired early. ${ }^{12}$ It is clear, however, that both the above measures breach no TRIPS obligations and promote the interest of Australian biotechnology and generic medicines SMEs.

Australia and other non-US TPPA nations could argue that the interests of their pharmaceutical and health-related SMEs would benefit if the TPPA defined pharmaceutical "innovation" (as it was in Annex 2C of the AUSFTA) on the basis of objectively demonstrated therapeutic significance assessed through the operation of science-based CER systems, as well as by the operation of competitive markets facilitated by strong anti-monopoly laws.

To benefit Australian public health and environmental policy, the TPPA should:

- expand the compulsory licensing exceptions that allow drug patents to be broken (with reasonable compensation) by local generic SMEs in a public health emergency;
- allow "springboarding" by Australian generic medicine SMEs on patent expiry, as well as export under patent; and

- permit the research use exemption that allows publicly funded Australian university researchers to experiment with the chemistry of drugs or other health-related technologies that are in patent without having to pay royalties.

\section{Improving multilateral investor-state dispute settlement}

Philip Morris (PM), a multinational tobacco company, lodged a submission with the USTR about the TPPA that outlined concerns over Australia's move toward plain packaging of cigarette packets. ${ }^{13,14}$ PM stated in its TPPA submission that plain packaging of cigarettes, if adopted, would amount to expropriation of intellectual property rights in its trademark, "limit the freedom of commercial free speech, significantly restrict competition and breach Australia's obligations under the WTO TRIPS Agreement". ${ }^{13}$ As a result, PM sought an investor-state dispute settlement provision in the TPPA that would allow it to sue governments that introduced legislation that impeded the investments of foreign corporations. ${ }^{15}$

Investor-state provisions appeared in the 1994 North American Free Trade Agreement (NAFTA) between the US, Canada and Mexico. ${ }^{16}$ Concerns about such provisions were a major reason for the failure of the Multilateral Agreement on Investment in $1998 .{ }^{17}$ Despite this, investor-state clauses have now become a controversial part of bilateral investment treaties and over 300 investor-state dispute settlement cases have been decided. ${ }^{18}$ Such provisions grant investors covered by them a right to initiate disputesettlement proceedings for damages in international arbitration proceedings against foreign governments impeding their investments ${ }^{19}$ without having to first seek damages in domestic courts. ${ }^{20}$ The lawyers controlling such arbitral proceedings are appointed and paid at the behest of the parties and do not necessarily take account of domestic public health and environment protections, creating a pro-investor jurisprudence. ${ }^{18}$

Investor-state challenges have occurred against a broad spectrum of public health and environmental protection legislation and policies. ${ }^{21}$ Examples include regulation against carcinogenic substances including chemicals that cause developmental disability, ${ }^{22}$ neurotoxins,${ }^{23}$ dangerous lawn pesticides ${ }^{24}$ and carcinogenic gasoline additives. ${ }^{25}$ Also impugned have been statutes on water protection, ${ }^{26}$ waste disposal ${ }^{27}$ and waste treatment. ${ }^{28}$ Canada has been sued under Chapter 11 of the NAFTA because its universal health care system allegedly interferes with US health care investment. ${ }^{29} \mathrm{~A}$ Canadian generic pharmaceutical company has used the same provisions to sue the US because its legal system promoted "evergreening". ${ }^{30}$ A US ban on cattle with suspected bovine spongiform encephalopathy ("mad cow disease") was also the subject of an investor-state claim. ${ }^{31}$

\section{Conclusion}

Australian TPPA negotiators have a responsibility both to this nation and our developing neighbours to promote regulatory coherence on CER and measures encouraging public healthrelated (eg, biotechnology and renewable energy) start-up SMEs. They have an equally strong obligation to resist the extension of TRIPS-Plus (Doha-Minus) and multilateral investor-state dispute settlement provisions (Box 2). 
2 Suggested public health and medicines provisions for the Trans-Pacific Partnership Agreement (TPPA)

- The parties affirm that as a matter of general international law, a non-discriminatory regulation for a public health or environmental purpose that affects a foreign investor or investment is not deemed expropriatory and compensable by damages.

- The parties affirm their right to make any term of this agreement, particularly those affecting their sovereign democratic right to protect public health and the environment, conditional upon the passage of legislation debated in parliament.

- Nothing in this agreement shall restrict or modify the ability of any party to take or maintain action to prevent or reduce tobacco or alcohol use, or restrict toxic chemicals or other dangerous substances, including their harms and costs.

- Nothing is this agreement shall restrict or modify the ability of any party to exercise all flexibilities provided by the Doha Declaration on TRIPS and Public Health, including preventing evergreening and anti-competitive behaviour, issuing compulsory licences for patented pharmaceuticals, permitting parallel importation, springboarding, export under patent, and measures that relate pharmaceutical prices and innovation to objectively demonstrated therapeutic significance and promote access to affordable medicines.

- The parties support the legitimate exercise of national, regional and local government sovereignty to protect population health and the environment including by passing laws and regulations that apply the precautionary principle.

- The standard of proof required to activate any mechanism in this agreement for enforcement of investor-state contracts in domestic courts shall exceed that whereby public health or environmental legislation or regulation activates the precautionary principle; further, under any such investor-state mechanism arbitral decisionmakers (if permitted) must take into account domestic constitutional and legislative public health protections and shall not award damages without all domestic legal remedies being exhausted.

- The parties may initiate unilateral interpretive declarations restricting the applicability of any investor-state dispute settlement provision in this agreement to their public health and environmental policies, legislation and regulations.

TRIPS $=$ Trade-Related Aspects of Intellectual Property Rights.

* Modified from Comment on TPPA by the Center for Policy Analysis on Trade and Health. ${ }^{32}$

Australia can rebut such attempts on the basis that they reopen the AUSFTA negotiations where an investor-state clause was expressly excluded. Considerable academic objections also exist to the expansion of multilateral investor-state arbitration as an undemocratic infringement on domestic sovereignty with considerable risks to public health and the environment. ${ }^{33}$ The Australian government appears aware of the risks. In answer to an opinion piece about the TPPA by the authors of this article, the then Australian Trade Minister Simon Crean wrote:

It is wrong to suggest that we are about to re-open obligations in relation to the Pharmaceutical Benefits Scheme that were settled in the 2005. If there are to be any changes to the scheme in the future, it would be part of a domestic policy debate in Australia ... we have serious reservations about the inclusion of investor-state dispute settlement provision in this agreement. We do not want new layers of red tape under the guise of trade liberalization. Australian negotiators will make this clear ... ${ }^{34}$
It is to be hoped in the interests of Australian public health and environment protection that these sentiments prevail.

\section{Competing interests}

Thomas Faunce has received Discovery Grants on the AUSFTA and PBS and Fraud in Pharmaceutical Industry from the Australian Research Council (ARC). The ARC was not involved in writing this paper.

\section{Author details}

Thomas A Faunce, BA LLB, BMed, PhD, ARC Future Fellow, College of Law and College of Medicine, Biology and the Environment

Ruth Townsend, RN, LLM, Lecturer in Bioethics and Health Law, College of Law and Medical School

Australian National University, Canberra, ACT.

Correspondence:Thomas.Faunce@anu.edu.au

\section{References}

1 Kelsey J. Introduction. In: Kelsey J, editor. No ordinary deal: unmasking free trade and the Trans-Pacific Partnership Agreement. Sydney: Allen \& Unwin, 2010.

2 Australian Government. Department of Foreign Affairs and Trade. Australia's participation in Trans-Pacific Partnership Agreement negotiations. Canberra: DFAT, 2010. http://www.dfat.gov.au/trade/fta/tpp/index.html (accessed Sep 2010).

3 Faunce TA. Global intellectual property protection for "innovative" pharmaceuticals: challenges for bioethics and health law. In: Bennett B, Tomossy GF, editors. Globalization and health: challenges for health law and bioethics. Dordrecht: Springer, 2007: 87-108.

4 Faunce TA. Reference pricing for pharmaceuticals: is the AustraliaUnited States Free Trade Agreement affecting Australia's Pharmaceutical Benefits Scheme? Med J Aust 2007; 187: 240-242.

5 Faunce TA, Shats K. Bilateral trade agreements as drivers of national and transnational benefit from health technology policy: implications of recent US deals for Australian negotiations with China and India. Aust $J$ Int Aff 2008; 62: 196-213.

6 Toohey B, Pharmaceutical Research and Manufacturers of America. Comment on: Office of the United States Trade Representative. Request for comments on proposed Trans-Pacific Partnership Trade Agreement. (Docket ID: USTR-2009-0041.) http://www.regulations.gov/search/Regs/ home.html\#documentDetail?R=0900006480a83600 (accessed Sep 2010).

7 World Trade Organization. Doha WTO Ministerial 2001: Ministerial declaration. Adopted on 14 November 2001. Geneva: WTO, 2001. http:// www.wto.org/english/thewto_e/minist_e/min01_e/mindecl_e.htm (accessed Sep 2010).

8 World Health Organization Commission on Intellectual Property Rights, Innovation and Public Health. Public health, innovation and intellectual property rights. Geneva: WHO, 2006. http://www.who.int/intellectualproperty/report/en/ (accessed Sep 2010).

9 Faunce T, Bai J, Nguyen D. Impact of the Australia-US Free Trade Agreement on Australian medicines regulation and prices. J Generic Med 2010; 7:18-29.

10 Haller T, Novartis Corporation. Comment on: Office of the United States Trade Representative. Request for comments on proposed Trans-Pacific Partnership Trade Agreement. (Docket ID: USTR-2009-0041.) http:// www.regulations.gov/search/Regs/home.html\#documentDetail?R= 0900006480a7c755 (accessed Sep 2010).

11 Section 301 of the Trade Act of 1974, as amended (19 U.S.C. § 2411).

12 Pharmaceutical Research and Manufacturers of America. PhRMA special 301 submission 2010. http://keionline.org/sites/default/files/USTR-20100003-0245.1.pdf (accessed Oct 2010).

13 McKittrick B, Philip Morris International. Comment on: Office of the United States Trade Representative. Request for comments on proposed Trans-Pacific Partnership Trade Agreement. (Docket ID: USTR-20090041.) http://www.regulations.gov/search/Regs/home.html\#documentDetail?R=0900006480a81289 (accessed Sep 2010).

14 Fielding S. Plain Tobacco Packaging (Removing Branding from Cigarette Packs) Bill 2009. http://parlinfo.aph.gov.au/parllnfo/download/legislation/bills/s724_first/toc_pdf/0916020.pdf;fileType\%3Dapplication\%2 Fpdf (accessed Sep 2010). 
15 Schneiderman D. Taking investments too far: exploitations in the semiperiphery. In: Cohen M, Clarkson S, editors. Governing under stress: middle powers and the challenge of globalization. London: Zed Books, 2004.

16 Roberts A. Power and persuasion in investment treaty interpretation: the dual role of states. Am J Int Law 2010; 104: 179-225.

17 Joint NGO statement on the multilateral agreement on investment (MAI) NGO/OECD Consultation on the MAI Paris: 27 October, 1997. http:// www.gwb.com.au/gwb/news/mai/ngos1.html (accessed Sep 2010).

18 Ganguly S. The investor-state dispute mechanism (ISDM) and a sovereign's power to protect public health. Columbia J Transnatl Law 1999; 38:113-124.

19 United Nations Conference on Trade and Development. Dispute settlement: investor-state. Geneva: UN, 2003. http://www.unctad.org/en/ docs/iteiit30_en.pdf (accessed Apr 2010).

20 Van Harten G, Loughlin M. Investment treaty arbitration as a species of global administrative law. Eur J Int Law 2006; 17: 121-150.

21 Esty D. Bridging the trade-environment divide. J Econ Perspect 2001; 15: 113-130.

22 Foreign Affairs and International Trade Canada. NAFTA — chapter 11 investment. Cases filed against the Government of Canada. Cromptom (Chemtura) Corp v Government of Canada. http://www.international.gc.ca/trade-agreements-accords-commerciaux/disp-diff/ crompton_archive.aspx?lang=en (accessed Sep 2010).

23 US Department of State. Ethyl Corp v Government of Canada. http:// www.state.gov/s/l/c3745.htm (accessed Apr 2010).

24 US Department of State. Dow AgroSciences LLC v Government of Canada. http://www.state.gov/s/l/c29885.htm (accessed Apr 2010).

25 Gaines S. Methanex Corp v United States of America. Am J Int Law 2006; 100: 683-689.
26 Sun Belt Water Inc. In the matter of the North American Free Trade Agreement. Chapter 11. Notice of intent to submit a claim to arbitration. http://www.international.gc.ca/trade-agreements-accords-commerciaux/assets/pdfs/Sunbelt.pdf (accessed Sep 2010).

27 US Department of State. V G Gallo v Government of Canada. http:// www.state.gov/s/l/c29744.htm (accessed Apr 2010).

28 US Department of State. Metalclad Corp v United Mexican States. http:// www.state.gov/s/l/c3752.htm (accessed Apr 2010).

29 Foreign Affairs and International Trade Canada. NAFTA — chapter 11 investment. Cases filed against the Government of Canada. Centurion Health Corporation v Government of Canada. http://www.international.gc.ca/trade-agreements-accords-commerciaux/disp-diff/ centurion_archive.aspx?lang=en (accessed Sep 2010).

30 US Department of State. Apotex Inc v United States of America. http:// www.state.gov/s/l/c27648.htm (accessed Apr 2010).

31 US Department of State. Cases regarding the border closures due to BSE concerns. http://www.state.gov/s/l/c14683.htm (accessed Sep 2010).

32 Brenner J, Center for Policy Analysis on Trade and Health (CPATH) Comment on: Office of the United States Trade Representative. Request for comments on proposed Trans-Pacific Partnership Trade Agreement. (Docket ID: USTR-2009-0041.) http://www.regulations.gov/search/Regs/ home.html\#documentDetail?R=0900006480a83af1 (accessed Sep 2010).

33 Public statement on the International Investment Regime. Toronto: Osgoode Hall Law School, York University, 2010; 31 Aug. http:// www.osgoode.yorku.ca/public_statement/ (accessed Sep 2010).

34 Crean S. Letter to the editor. Canberra Times 2010; 17 Mar.

(Received 5 Jul 2010, accepted 13 Sep 2010) 